\title{
Janina Druszcz, Świętość matki w hagiografii, nauczaniu i praktyce Kościoła katolickiego Olsztyn 2007, 342 s.
}

Książka, powstała w wyniku opracowania dysertacji doktorskiej, jest to, jak napisał jej recenzent - ks. prof. dr hab. Józef Kulisz SJ, „Pierwsze odważne opracowanie tematu świętości i roli matki w życiu, w którym stawia ją powołanie”. Może właśnie dlatego, że jest to dysertacja akademicka, wyróżnia się perfekcyjnym schematem metodologicznym. Została skomponowana z 3 części: A. Hagiografia; B. Nauczanie; C. Praktyka, i każdej z nich został przyporządkowany odpowiedni materiał ujęty w rozdziały:

- hagiograficzny: rozdział I. Złota Legenda Jakuba de Voragine (1253-1270) i rozdział II. Żywoty Świętych Piotra Skargi (1579);

- profetyczny: rozdział III. Świętość małżeńska w Katechizmie Rzymskim (1566),

rozdział IV. Encyklika Papieża Piusa XI „Casti connubii” (1930),

rozdział V. Sobór Watykański II (1962-1965),

rozdział VI. Katechizm Kościoła Katolickiego (1992),

rozdział VII. Nauczanie Papieża Jana Pawła II (1978-2005);

- praktyczny: rozdział VIII. Beatyfikacje i kanonizacje Papieża Jana Pawła II (1978-2005).

Zasadniczy korpus książki został poprzedzony przez wprowadzający Wstęp (s. 7-8) i zamknięty przez Zakończenie (s. 299-314)

Książkę uzupełnia i nadaje jej głębszy charakter naukowo-praktyczny Wykaz skrótów (s. 315-318) oraz Bibliografia (s. 319-342).

Trzymając się strony metodologicznej książki, należy zwrócić uwagę na specyficznie potraktowany Wstęp, poświęcony jedynie metodzie właśnie, nie dający charakterystyki tła naukowego, socjalnego, czy eklezjalnego dla podejmowanego tematu.

Bardziej konwencjonalną formę nadała Autorka Zakończeniu, podsumowując w nim wyniki przeprowadzonych badań.

W Bibliografii utrzymała klasyczny podział na źródła i opracowania, aczkolwiek zaskakujące są proporcje - źródeł jest niemal tyle samo co opracowań, co może uzasadniać nowatorski charakter tematu.

Brak jest indeksu rzeczowego i osobowego, coraz częściej stosowanego przez autorów pragnących dzielić się swoją pracą i skłaniać potencjalnych odbiorców do poczytności dzieł. 
Dużą wartością książki jest sam temat świętości, podejmowany w czasie niesprzyjającym pielęgnowaniu ani religijnego życia, ani praktykowaniu powszedniego przeobrażania go na wzór życia Jezusa Chrystusa i według wymogów Jego Ewangelii. W epoce niczym niepohamowanego liberalizmu, hedonizmu nakręcanego przez lobby komercyjno-rozrywkowe, źle pojętej wolności i egoistycznego konsumizmu, pochylenie się nad świętością życia, osiąganą na drodze chrześcijańskiego radykalizmu, jest ważne zarówno dla młodych, wybierających model własnego życia, jak dla zagubionych w pościgu za materialnym sukcesem zapewniającym dobrobyt i wygodę jedynie tu i teraz. Wszak świętość również pielęgnowana tu i teraz, daje komfort godziwości i otwiera perspektywę na wieczność.

Wartością dodaną książki jest ukazanie świętości matki, podczas gdy od wieków w chrześcijaństwie uprzywilejowanym modelem świętości było dziewicze życie wybierane z miłości do Chrystusa i ze względu na Niego, poniekąd uzasadnione przez słowa Jezusa (Łk 10,42), niejako preferujące życie oddane Bogu jako „lepszą cząstkę". Matka natomiast uprzednio ofiaruje swoje dziewictwo rodzinie i, mimo że współpracuje ze Stwórcą dając i chroniąc życie oraz naśladując wzór Najświętszej z Matek, obiera tę „gorszą z cząstek”. Zatem dobrze, że Autorka wydobyła $\mathrm{z}$ historii Kościoła postaci cieszące się chwałą ołtarzy i pociągające do naśladowania swoich postaw czy to w zakresie dobroczynności, obrony życia dziecka, czy też w zakresie zbożnego życia na co dzień. Wszystkie te zakresy są dziś ogromnie ważne, bo czynią życie bardziej ludzkim, aczkolwiek na pewno nie wyczerpują wszystkich potrzeb współczesnego świata, wymagającego nowej ewangelizacji i nowych wzorców osobowych. Myślę, że „palącą” potrzebą jest wydobycie wzorca wspomagającego ewangeliczne wychowanie młodego człowieka do życia w stałym związku małżeńskim i do poszanowania życia.

Autorka swoim zainteresowaniem objęła prawie 20 wieków europejskiego chrześcijaństwa, większą uwagę poświęcając okresowi od XVI do XX wieku. Obierając sobie Ztotą Legendę za źródło do opracowania, sięgnęła do starożytnych przykładów świętych matek. Zaznaczyła przy tym, że dostrzeżone one zostały jednak ze względu na „owoce” ich życia, czyli wychowanie dzieci skłonnych właśnie do „obrania lepszej cząstki”, to jest do życia w dziewictwie, jak św. Paula, matka św. Eustochium (s. 17) lub dzięki fundacji klasztorów, głównie przez matki wdowy, ułatwiających życie w dziewictwie (s. 15). Inną grupą świętych matek były heroiczne męczenniczki, które dla zachowania wierności Chrystusowi decydowały się osierocić dzieci, jak św. Felicyta i Perpetua. (s. 1213). Jeszcze jednym modelem świętości kobiety była niewiasta żyjąca w dziewiczym małżeństwie, a ponadto wspierająca w nim swojego małżonka, jak św. Daria, żona Chryzanta (s. 21). Model ów przetrwał do okresu średniowiecza i w Polsce znalazł potwierdzenie w małżeństwie księcia Bolesława Wstydliwego i św. Kingi. 
Janina Druszcz ukazała też współczesny model świętej matki, żyjącej w zdrowym naturalnym małżeństwie, wspierającej się wzajemnie ze świętym małżonkiem, jak błogosławiona Maria Corsini Beltrame Quatrocchi i Alojzy, aczkolwiek i w tym przypadku mocno podkreślaną zasługą było wychowanie dzieci do życia konsekrowanego (s. 291-292).

Ogromnie pożądanym wzorcem jest święta matka heroicznie broniąca życie poczętego dziecka, jak bł. Joanna Berett Molla, oddająca mu swoje życie. Jako lekarz była w pełni świadoma ryzyka utraty życia, jednak podjęła je (s. 278-279). Myślę, że do podobnych zachowań zdolne są współczesne kobiety, a prawie identyczny przykład - również matki lekarza, oddającej swoje życie by uratować poczętego syna - jeszcze przed beatyfikacją Joanny, zdarzył się przed kilkoma laty w Polsce.

Warto nadmienić, że bohaterskie matki żyły w rodzinach, podstawą których było sakramentalne małżeństwo, że były wzorowymi żonami wspierającymi swoich małżonków lub, jak bł. Elżbieta Canori Mora, modlącymi się o nawrócenie niegodnych małżonków. Dziś, gdy jedynym motywem łączenia się ludzi w pary inicjujące rodzinę jest ludzka miłość, niewłączana w potencjał Bożej miłości, ogromnie ważne jest wiązanie świętości życia małżonków z łaską sakramentalną. Każda $\mathrm{z}$ heroicznych matek czerpała siły $\mathrm{z}$ pełnego uczestniczenia w ofierze Mszy św., z częstej Komunii Świętej i obdarzała bliskich, również tych niegodnych i niewiernych, modlitwą wstawienniczą. Należałoby podkreślać, że warunkiem pełnego życia sakramentalnego umacniającego małżonków jest wiążący ich sakrament małżeństwa, którego brak odcina małżonków od oczyszczającego sakramentu pokuty i pojednania i Komunii Świętej.

Zaletą recenzowanej książki jest omówienie nauczania Kościoła odnośnie do istoty macierzyństwa, godności matki, jej roli w rodzinie, w Kościele i w świecie i, co ogromnie ważne, podkreślenie niezbywalnego łączenia macierzyństwa z sakramentalnym małżeństwem. Autorka, omawiając dokumenty Kościoła opracowane przez Sobór Trydencki, wydane w postaci Katechizmu Rzymskiego z 1566 (s. 85-104), oraz Sobór Watykański II (s. 137-164), autorów Katechizmu Kościoła Katolickiego z 1992 (s. 165-208) oraz nauczanie papieży Piusa XI (s. 105-136) i Jana Pawła II (s. 209-298), ukazała chrześcijańskie wymogi ułatwiające osiąganie świętości życia w rodzinie. Wiele uwagi poświęciła sakramentalności małżeństwa i wynikającej z niej łaski: wzajemna pomoc małżonków, obdarowanie przez Boga potomstwem (s. 110-117), cześć rodziców ze strony dzieci (s. 90-96; 184-194), wzajemne apostołowanie w rodzinie (s. 139-150), zdolność do chrześcijańskiego wychowywania (s. 250-251) oraz apostołowanie sakramentalnej rodziny w środowisku życia (s. 157-162), dowartościowanie życia ludzkiego, dowartościowanie roli matki (s. 213-218; 222-236; 244-257) i zobowiązania: m.in. do wierności małżeńskiej (s. 96-104; 117-127;194-208), do przemiany mentalności chrześcijańskiej (s. 162-164). 
Spośród wielu zalet opracowania, począwszy od wyboru tematu i solidnego opracowania, dostrzegam istotny jego brak - niedostrzeżenie wzorczej postawy Najświętszej Maryi Panny - Matki Bożej, obdarzonej macierzyńskimi tytułami odnośnie do nas ludzi (por. J 19, 26-27) i Kościoła. Jest nie tylko wzorem wzorów przytoczonych w książce, ale również Orędowniczką i Wspomożycielką dla wszystkich pokoleń chrześcijańskich niewiast. Szkoda zatem, że nie znalazła miejsca w książce traktującej o świętości matek. Mimo to warto je czytać i promować z uwagi na wskazanie sakramentalnego małżeństwa jako skutecznej drogi do osiągnięcia świętości życia.

Zofia Pałubska 